\title{
Sr-bearing high-pressure tourmaline from the Kreuzeck Mountains, Eastern Alps, Austria
}

\author{
ANDREAs ERTL ${ }^{1 *}$, DAN TOPA $^{2}$, Gerald GIESTER ${ }^{1}$, GEORGE R. ROSSMAN $^{3}$, EkKehart TILLMANNS ${ }^{1}$ \\ and JÜRGEN KONZETT ${ }^{4}$
}
${ }^{1}$ Institut für Mineralogie und Kristallographie, Geozentrum, Universität Wien, Althanstrasse 14, 1090 Vienna, Austria *Corresponding author, e-mail: andreas.ertl@a1.net
${ }^{2}$ Zentrale Forschungslaboratorien, Naturhistorisches Museum, Burgring 7, 1010 Vienna, Austria
${ }^{3}$ Division of Geological and Planetary Sciences, California Institute of Technology, Pasadena, CA 91125-2500, USA
${ }^{4}$ Institut für Mineralogie und Petrologie, Universität Innsbruck, Innrain 52, 6020 Innsbruck, Austria

\begin{abstract}
A detailed investigation was conducted on high-pressure ( 1.4 GPa) tourmaline from an Eoalpine mafic eclogite, which occurs in the Kreuzeck Mountains, Eastern Alps, Austria. Tourmaline from this locality contains the highest amount of $\mathrm{Sr}^{2+}$ (up to $0.68 \mathrm{wt} \% \mathrm{SrO})$ known to date. The space group is $R 3 m$ with unit-cell parameters $a=15.944(1), c=7.202(1) \AA, V=1585.5(3) \AA^{3}$. Analyses by a combination of electron microprobe, optical absorption spectroscopy and crystal-structure refinement $(R 1=1.31 \%)$ result in the structural formula ${ }^{X}\left(\mathrm{Na}_{0.85} \mathrm{Ca}_{0.08} \mathrm{Sr}_{0.06} \mathrm{~K}_{0.01}\right)_{\Sigma 1.00}{ }^{Y}\left(\mathrm{Mg}_{1.68} \mathrm{Al}_{0.70} \mathrm{Fe}_{0.37}^{3+} \mathrm{Ti}_{0.10}^{4+} \mathrm{Fe}_{0.11}^{2+} \mathrm{Ca}_{0.03} \mathrm{Cr}_{0.01}^{3+}\right)_{\Sigma 3.00}{ }_{\left(\mathrm{Al}_{5.15} \mathrm{Mg}_{0.80}\right.}$ $\left.\mathrm{Fe}_{0.05}^{3+}\right)_{\Sigma 6.00}{ }^{T}\left(\mathrm{Si}_{5.82} \mathrm{~B}_{0.10} \mathrm{Al}_{0.08} \mathrm{O}_{18}\right)\left(\mathrm{BO}_{3}\right)_{3}{ }^{V}(\mathrm{OH})_{3}{ }^{W}\left[\mathrm{O}_{0.45}(\mathrm{OH})_{0.35} \mathrm{~F}_{0.20}\right.$. The $T$ site contains mainly Si and additionally small amounts

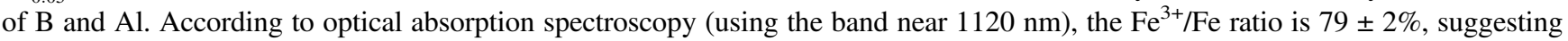
that this high-pressure tourmaline crystallized under oxidizing conditions. It has a significant oxy-dravite component. A near-rim zone contains $0.6 \mathrm{wt} \% \mathrm{Cr}_{2} \mathrm{O}_{3}, 0.5 \mathrm{wt} \% \mathrm{PbO}_{2}, 0.2 \mathrm{wt} \% \mathrm{NiO}$ and $0.1 \mathrm{wt} \% \mathrm{~V}_{2} \mathrm{O}_{3}$. Only a small $\mathrm{F}$ content was found by structure refinement. There is no evidence for significant $X$-site vacancy in the investigated tourmaline zones. We assume that the original boron source for tourmaline crystallization in the eclogite, i.e. tourmaline-bearing pegmatites in the country-rock, were influenced by a Sr-bearing marble.
\end{abstract}

Key-words: high-pressure tourmaline; oxy-dravite; Kreuzeck Mountains; Eastern Alps; crystal structure; optical absorption spectroscopy.

\section{Introduction and previous work}

The general chemical formula of the tourmaline-supergroup minerals can be written as $X Y_{3} Z_{6}\left[T_{6} \mathrm{O}_{18}\right]\left(\mathrm{BO}_{3}\right)_{3} V_{3} W$, as proposed by Henry et al. (2011). These authors and Hawthorne $(1996,2002)$ suggest occupancies by the following most common constituents:

$X=\mathrm{Na}, \mathrm{K}, \mathrm{Ca}, \square$ (vacancy),

$Y=\mathrm{Mg}, \mathrm{Fe}^{2+}, \mathrm{Mn}^{2+}, \mathrm{Al}, \mathrm{Li}, \mathrm{Fe}^{3+}, \mathrm{Cr}^{3+}, \mathrm{V}^{3+}$,

$\mathrm{Z}=\mathrm{Al}, \mathrm{Mg}, \mathrm{Fe}^{3+}, \mathrm{V}^{3+}, \mathrm{Cr}^{3+}$,

$T=\mathrm{Si}, \mathrm{Al}, \mathrm{B}$,

$V=\mathrm{OH}, \mathrm{O} ; W=\mathrm{OH}, \mathrm{F}, \mathrm{O}$.

Substantial research efforts have been devoted to analytical work and interesting crystal-chemical relationships between structural features and site-occupancies have been established (e.g. Bosi \& Lucchesi, 2004, 2007; Lussier et al., 2009; Ertl et al., 2010b and c; Bosi, 2018).

A variety of substituents for $\mathrm{Si}$ at the $T$ site have been described. A substitution of $\mathrm{Al}^{3+}$ for $\mathrm{Si}^{4+}$ was first proposed by Buerger et al. (1962). Foit (1989) described a positive correlation between ${ }^{[4]} \mathrm{Al}$ and the $\langle T-\mathrm{O}\rangle$ distance.
MacDonald \& Hawthorne (1995) have shown by crystalstructure analyses in combination with chemical analyses that $\mathrm{Mg}$-rich tourmaline can contain significant amounts of ${ }^{[4]} \mathrm{Al}$ and that there is a good linear positive correlation between $\langle T-\mathrm{O}\rangle$ and ${ }^{[4]} \mathrm{Al}$.

Structure studies showed that B substitutes for $\mathrm{Si}$ in significant amounts at the tetrahedral site in natural tourmaline (Ertl et al., 1997, 2007, 2008; Lussier et al., 2008). Structure studies by Hughes et al. (2004) and Ertl \& Hughes (2002) on Fe-bearing olenite and on Al-rich schorl also showed substantial amounts of ${ }^{[4]} \mathrm{B}$. "Oxy-rossmanite", with a $T$-site occupancy of $\left(\mathrm{Si}_{5.51} \mathrm{Al}_{0.25} \mathrm{~B}_{0.24}\right)$, gave for the first time a clear indication that it is possible to have significant amounts of both ${ }^{[4]} \mathrm{B}$ and ${ }^{[4]} \mathrm{Al}$ in an Al-rich tourmaline (Ertl et al., 2005). Although the structure refinements showed significant amounts of ${ }^{[4]} \mathrm{B}$, the $\langle T-\mathrm{O}\rangle$ bond-lengths $(\sim 1.620 \AA)$ masked the incorporation of ${ }^{[4]} \mathrm{B}$ because of the concomitant incorporation of ${ }^{[4]} \mathrm{Al}$ (Ertl et al., 2005).

Chromium- and Mg-rich green tourmaline from Outokumpu, Finland, with $0.34 \mathrm{wt} \% \mathrm{SrO}$ was described by Peltola et al. (1968). This tourmaline with unit-cell 
parameters $a=15.96, c=7.22 \AA$ contains $10.6 \mathrm{wt} \% \mathrm{MgO}$, $9.6 \mathrm{wt} \% \mathrm{Cr}_{2} \mathrm{O}_{3}, 0.6 \mathrm{wt} \% \mathrm{~V}_{2} \mathrm{O}_{3}, 2.0 \mathrm{wt} \% \mathrm{Na}_{2} \mathrm{O}$ and $1.0 \mathrm{wt} \%$ $\mathrm{CaO}$. In the Outokumpu area, Cr-rich tourmaline is associated with other Cr-bearing minerals which frequently occur in contact skarns between serpentinites and quartzites.

A high-pressure tourmaline formation resulting from a saline aqueous fluid activity in mafic eclogites from the Kreuzeck Mountains (Austroalpine basement), Eastern Alps, Austria, was described by Konzett et al. (2012). These authors described tourmaline samples with 7.9-10.2 wt\% $\mathrm{MgO}$, 3.6-8.3 wt\% $\mathrm{FeO}_{\text {tot }}, 0.7-3.4$ wt\% $\mathrm{TiO}_{2}, 2.1-$ $2.6 \mathrm{wt} \% \mathrm{Na}_{2} \mathrm{O}, 0.5-1.2 \mathrm{wt} \% \mathrm{CaO}$. The $\mathrm{SrO}$ content in these samples ranges from 0.15 to $0.56 \mathrm{wt} \%$ (Konzett et al., 2012). A reinvestigation of this eclogitic tourmaline was carried out to obtain further data, in particular on the cation occupation of the individual atomic positions.

\section{Petrological setting}

The tourmaline-bearing eclogite sample was collected from an eclogite lens of $\sim 50 \mathrm{~m}$ in diameter enclosed in metapelitic gneisses of the Polinik Unit, the latter forming part of the Austroalpine basement units of the Eastern Alps within the Kreuzeck Mountains $\left(46^{\circ} 53^{\prime} 32^{\prime \prime} \mathrm{N}, 13^{\circ} 10^{\prime} 19^{\prime \prime} \mathrm{E}\right)$ in the state of Carinthia, Austria. The brown coloured tourmaline investigated in this study is part of an eclogite assemblage comprising garnet + omphacite + quartz + epidote-group phases + calcic amphibole + K-feldspar + rutile + apatite + zircon that formed under peak metamorphic $P-T$ conditions of $\sim 2.1 \mathrm{GPa}$ and $\sim 650{ }^{\circ} \mathrm{C}$ during Eo-Alpine metamorphism (Konzett et al., 2012). Tourmaline inclusions in garnet and omphacite $+\mathrm{K}$-feldspar inclusions in tourmaline are most consistent with a high-pressure origin of the tourmaline, however, with a possible continuation of tourmaline growth during uplift and decompression. Secondary ion mass spectrometry (SIMS) U-Pb isotopic dating by using eight data points (zircon) yielded a well-constrained intercept age of $90 \pm 9 \mathrm{Ma}$ (Konzett et al., 2012). These authors suggested as possible source of B the metapelitic country rocks that were pre-enriched in B by the intrusion of tourmaline-bearing pegmatites during Permian metamorphism. Laser-ablation inductively coupled plasma mass spectrometry (LA-ICP-MS) analysis of primary aqueous saline fluid inclusions trapped in quartz coexisting with tourmaline under eclogite-facies conditions show high concentrations of $\mathrm{Ca}(1.6-2.7$ wt\%), K (3500-4900 $\mu \mathrm{g} / \mathrm{g})$, B (250$370 \mu \mathrm{g} / \mathrm{g}), \mathrm{Sr}(490-1080 \mu \mathrm{g} / \mathrm{g})$ and $\mathrm{Pb}(8-16 \mu \mathrm{g} / \mathrm{g})$ with total solute concentrations of up to $9.3 \mathrm{wt} \%$ (Konzett et al., 2012).

The eclogite suite to which the tourmaline-bearing sample belongs is characterized by bulk compositions rich in $\mathrm{Fe}, \mathrm{Ti}, \mathrm{P}, \mathrm{Zr}$ and $\mathrm{Sr}$ relative to MOR basalts and by compositional variations indicating progressive differentiation of a mafic magma with Fe-Ti oxides and apatite as important igneous phases and metasomatic addition of $\mathrm{K}$ and $\mathrm{Sr}$. The systematics of bulk $\mathrm{Ti}-\mathrm{V}-\mathrm{Zr}-\mathrm{P}-\mathrm{Nb}-\mathrm{Y}$ contents of the eclogites points to a within-plate rather
Table 1. Crystallographic data and refinement details for highpressure tourmaline from the Kreuzeck Mountains, Eastern Alps, Austria. $a, c(\AA)$

$V\left(\AA^{3}\right)$

Crystal size $\left(\mathrm{mm}^{3}\right)$

Collection mode, $2 \theta_{\max }\left(^{\circ}\right)$

$h, k, l$ ranges

Number of frames

Total reflections measured

Unique reflections

$R 1^{\mathrm{a}}(F), w R 2^{\mathrm{b}}\left(F^{2}\right), R_{\text {int }}^{\mathrm{c}}(\%)$

Flack $x$ parameter

"Observed" refls. $\left[F_{\mathrm{o}}>4_{\left(F_{\mathrm{o}}\right)}\right]$

Extinct. coefficient

Refined parameters

Goodness-of-Fit ${ }^{\mathrm{d}}$

$\Delta \sigma_{\min }, \Delta \sigma_{\max }\left(\mathrm{e} / \AA^{3}\right)$
$15.944(1), 7.202(1)$

$1585.5(3)$

$0.15 \times 0.13 \times 0.10$

Full sphere, 79.98

$\overline{2} 8 / 28, \overline{2} 8 / 28, \overline{1} 3 / 12$

728

31855

2351

$1.31 \%, 3.59 \%, 1.86 \%$

$0.046(18)$

2340

$0.0011(2)$

96

1.115

$-0.47,0.69$
Note: X-ray radiation: $\operatorname{Mo} K \alpha(\lambda=0.71073 \AA) ; Z=3$; space group $R 3 m$ (no. 160); multi-scan absorption correction; refinement on $F^{2}$. Frame width, scan time, detector distance: $2^{\circ}, 35 \mathrm{~s}, 35 \mathrm{~mm}$. Scan mode: sets of $\varpi$ and $\theta$ scans.

${ }^{\mathrm{a}} R 1=\Sigma|| F_{\mathrm{o}}|-| F_{\mathrm{c}}|| / \Sigma\left|F_{\mathrm{o}}\right|$.

$\mathrm{b}_{w R 2}=\left\{\Sigma\left[w\left(F_{\mathrm{o}}{ }^{2}-F_{\mathrm{c}}{ }^{2}\right)^{2}\right] / \Sigma\left[w\left(F_{\mathrm{o}}{ }^{2}\right)^{2}\right]\right\}^{1 / 2}$.

$w=1 /\left[\sigma^{2}\left(F_{\mathrm{o}}{ }^{2}\right)+(a P)^{2}+b P\right], P=\left[2 F_{\mathrm{c}}{ }^{2}+\operatorname{Max}\left(F_{\mathrm{o}}{ }^{2}, 0\right)\right] / 3$.

${ }^{\mathrm{c}} R_{\text {int }}=\Sigma \mid F_{\mathrm{o}}{ }^{2}-F_{\mathrm{o}}{ }^{2}($ mean $) \mid / \Sigma\left[F_{\mathrm{o}}{ }^{2}\right]$.

${ }^{\mathrm{d}} \mathrm{GooF}=S=\left\{\Sigma\left[w\left(F_{\mathrm{o}}{ }^{2}-F_{\mathrm{c}}{ }^{2}\right)^{2}\right] /(n-p)\right\}^{1 / 2}$.

than MORB-type environment of protolith formation (Konzett et al., 2012).

\section{Experimental details}

\subsection{Crystal-structure refinement}

A fragment of a rock-forming tourmaline crystal (from zone 1 , which is relatively homogeneous and significantly enriched in Sr; see details in Table 1 and Fig. 1) was separated and subsequently studied on a Bruker AXS Kappa APEXII single-crystal diffractometer equipped with a charge-coupled device (CCD) area detector and an Incoatec Microfocus Source $\mathrm{I} \mu \mathrm{S}$ ( $30 \mathrm{~W}$, multilayer mirror, MoK $\alpha$ ). Redundant data were collected at room temperature (up to $80^{\circ} 2 \theta$ ) for an approximate sphere of reciprocal space, and were integrated and corrected for Lorentz and polarization factors, and absorption correction by evaluation of partial multiscans, using the Bruker programs SaintPlus and SADABS (Bruker AXS Inc., 2001). The structure was refined with SHELXL97 (Sheldrick, 1997, 2008) using scattering factors for neutral atoms and a tourmaline starting model from Ertl et al. (2010b). The $\mathrm{H}$ atom bonded to the O3 atom was located from a difference-Fourier map and subsequently refined. Refinement was done with anisotropic displacement parameters for all non-H atoms. Table 1 provides crystal data and details of the structure refinement. The refinement converged to an $R 1(F)$ value of $\sim 1.3 \%$ (Table 1). In Table 2, the atomic parameters and equivalent isotropic-displacement parameters are listed, and in Table 3 selected interatomic distances are presented. The CIF file of this refinement is deposited in the Supplementary Materials 

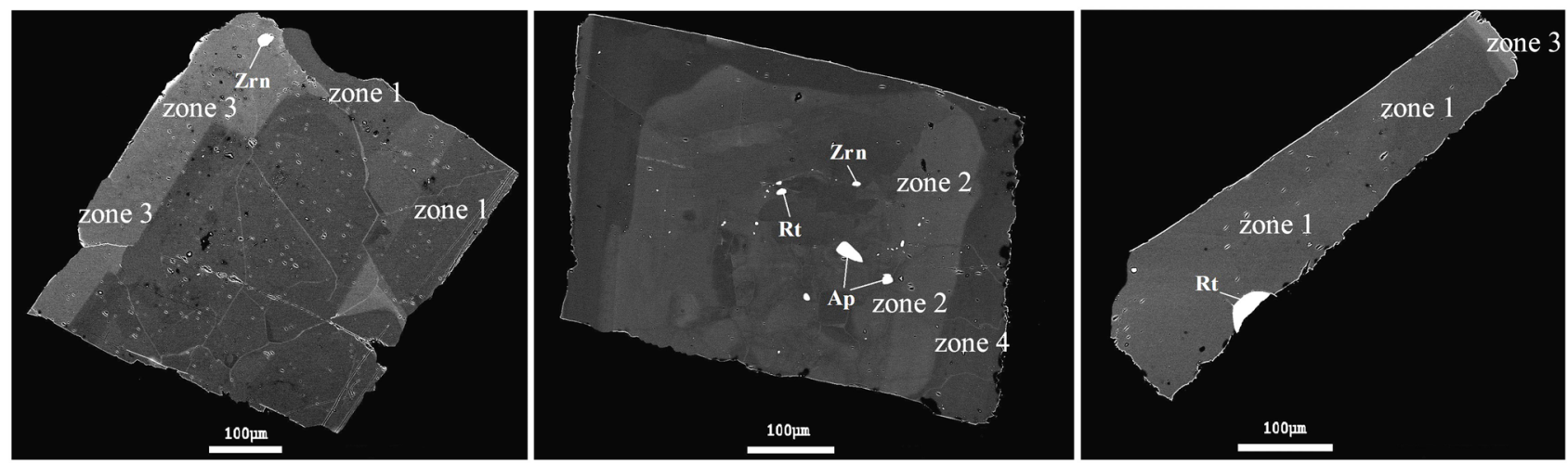

Fig. 1. Back-scattered electron image from polished grains of the investigated tourmaline crystal from the Kreuzeck Mountains, Eastern Alps, Austria. All fragments belong to the same rock-forming single crystal. The different zones can be distinguished optically and chemically (Table 4). Zrn, zircon; Rt, rutile; Ap, apatite.

Table 2. Atomic parameters for tourmaline from the Kreuzeck Mountains, Eastern Alps, Austria.

\begin{tabular}{|c|c|c|c|c|c|}
\hline Site & $x$ & $y$ & $z$ & $U_{\mathrm{eq}}$ & Occ. \\
\hline$X$ & 0 & 0 & $0.22936(12)$ & $0.0179(2)$ & $\mathrm{Na}_{0.93} \mathrm{Sr}_{0.07(2)}$ \\
\hline$Y$ & $0.12512(2)$ & $0.06256(1)$ & $0.63163(4)$ & $0.00719(8)$ & $\mathrm{Mg}_{0.804} \mathrm{Fe}_{0.196(2)}$ \\
\hline$Z$ & $0.29822(1)$ & $0.26173(1)$ & $0.61154(3)$ & $0.00539(5)$ & $\mathrm{Al}_{1.00}$ \\
\hline$T$ & $0.19188(1)$ & $0.19000(1)$ & $-0.00103(2)$ & $0.00432(4)$ & $\mathrm{Si}_{0.990} \mathrm{~B}_{0.010(2)}$ \\
\hline H3 & $0.261(2)$ & $0.1305(11)$ & $0.401(4)$ & $0.054(9)$ & $\mathrm{H}_{1.00}$ \\
\hline $\mathrm{O} 1$ & 0 & 0 & $0.77347(18)$ & $0.0146(3)$ & $\mathrm{O}_{0.80} \mathrm{~F}_{0.20(5)}$ \\
\hline $\mathrm{O} 4$ & $0.09279(3)$ & $0.18558(6)$ & $0.06948(10)$ & $0.0096(1)$ & $\mathrm{O}_{1.00}$ \\
\hline O5 & $0.18378(6)$ & $0.09189(3)$ & $0.09053(10)$ & $0.0096(1)$ & $\mathrm{O}_{1.00}$ \\
\hline O6 & $0.19604(3)$ & $0.18620(4)$ & $0.77725(6)$ & $0.00809(7)$ & $\mathrm{O}_{1.00}$ \\
\hline $\mathrm{O} 7$ & $0.28485(3)$ & $0.28478(3)$ & $0.07907(6)$ & $0.00787(7)$ & $\mathrm{O}_{1.00}$ \\
\hline O8 & $0.20942(3)$ & $0.27016(4)$ & $0.44112(7)$ & $0.00891(7)$ & $\mathrm{O}_{1.00}$ \\
\hline
\end{tabular}

Note: For the definition of $U_{\text {eq }}$ see Fischer \& Tillmanns (1988).

(freely available online on the GSW website of the journal, https://pubs.geoscienceworld.org/eurjmin).

\subsection{Chemical analyses}

Crystal fragments of the same tourmaline crystal that was used for the structure refinement were prepared as a section (polished on one side) for chemical analysis. The composition of the high-pressure tourmaline was determined on a JXA-8530F "HyperProbe" field-emission electron-probe microanalyzer equipped with five wavelength-dispersive spectrometers (Naturhistorisches Museum, Vienna). The operating conditions were: $15 \mathrm{kV}$ accelerating voltage, $20 \mathrm{nA}$ beam current, 5-10 $\mu \mathrm{m}$ (defocused) beam diameter, $10 \mathrm{~s}$ counting time for peak, and $5 \mathrm{~s}$ for background intensities for all major and minor elements. The trace elements (K, V, Ni, Zn, Sr and Pb) were counted for $200 \mathrm{~s}$ on peak and $70 \mathrm{~s}$ on background positions. Natural and synthetic standards were used. Data reduction was done with an online JEOL ZAF correction program. The mean values for the detection limits (in ppm) of mentioned trace elements (same order as above) are: 20(1), 69(3), 103(14), 154(7),
67(2) and 84(11), respectively. Table 4 contains the analytical data of the different zones of the high-pressure tourmaline. The crystal-chemical formulae were calculated on the basis for $31(\mathrm{OH}, \mathrm{O}, \mathrm{F})$. The amount of $\mathrm{B}_{2} \mathrm{O}_{3}$ for zone 1 was calculated using the structure refinement (SREF) data.

\subsection{Optical and near-infrared absorption spectroscopy}

Tourmaline sample GRR 3534 was extracted from the same zone and the same single crystal as the sample that was used for the structure refinement and was prepared for optical absorption spectroscopy as a doubly polished section, $0.156 \mathrm{~mm}$ thick, oriented with the c-axis in the plane of the section. Plane-polarized optical and near-IR absorption spectra in the 390-1660 $\mathrm{nm}$ range were obtained on a homemade diode array spectrometer described in Taran \& Rossman (2001). Optical absorption spectroscopy was used to estimate the percentage of $\mathrm{Fe}^{2+}$. For this purpose the band near $1120 \mathrm{~nm}$ was used, because it is the band that is best separated from other bands (Fig. 2). We conclude that this tourmaline contains $79 \pm 2 \% \mathrm{Fe}^{3+}$. Usually Mössbauer 
Table 3. Selected interatomic distances in tourmaline from the Kreuzeck Mountains, Eastern Alps, Austria.

\begin{tabular}{rlrl}
\hline$X-$ & & $T-$ & \\
O2 $\times 3$ & $2.4894(10)$ & O6 & $1.6006(5)$ \\
O5 $\times 3$ & $2.7274(8)$ & O7 & $1.6042(5)$ \\
O4 $\times 3$ & $2.8093(9)$ & O4 & $1.6271(3)$ \\
Mean & $2.675(1)$ & O5 & $1.6421(3)$ \\
$Y-$ & & Mean & $1.6185(4)$ \\
O1 & $2.0071(7)$ & B- & \\
O6 $\times 2$ & $2.0089(5)$ & O2 & $1.3693(12)$ \\
O2 $\times 2$ & $2.0104(5)$ & O8 $(\times 2)$ & $1.3769(7)$ \\
O3 & $2.1272(9)$ & Mean & $1.3744(9)$ \\
Mean & $2.0288(6)$ & & \\
$Z$ - & & & \\
O6 & $1.8886(5)$ & & \\
O8 & $1.8949(5)$ & & \\
O7 & $1.9020(5)$ & & \\
O8 & $1.9285(6)$ & & \\
O7 & $1.9602(5)$ & & \\
O3 & $1.9871(4)$ & & \\
Mean & $1.9269(5)$ & & \\
\hline Standard & & & \\
\hline
\end{tabular}

Standard deviation in brackets.

spectroscopy is used for the estimation of the valence states of $\mathrm{Fe}$ in tourmaline. Advantages of using optical absorption spectroscopy for such an estimation are that it can be obtained much faster compared to Mössbauer spectroscopy and the estimation can be done on small, individual areas of a crystal, down to $100 \times 100 \mu \mathrm{m}^{2}$

\section{Results}

\subsection{Optical and near-infrared absorption spectra}

The optical spectrum is typical of iron-containing tourmalines showing prominent $\mathrm{Fe}^{2+}$ absorption bands near 1120 and $720 \mathrm{~nm}$ and $\mathrm{Fe}^{2+}-\mathrm{Ti}^{4+}$ intervalence charge-transfer absorption near $460 \mathrm{~nm}$, which accounts mainly for the brown bulk colour of the tourmaline. Of particular note is the fact that the iron bands are much more intense in the $\mathbf{E} \perp \mathbf{c}$ direction than in the $\mathbf{E} \| \mathbf{c}$ direction. This is an indication that the $\mathrm{Fe}^{2+}$ is interacting with a significant amount of $\mathrm{Fe}^{3+}$ (Mattson \& Rossman, 1987). To estimate the proportion of the two oxidation states, the intensity of the $\mathrm{Fe}^{2+}$ bands in the dravite was compared to the intensity of the $\mathrm{Fe}^{2+}$ bands in two zones (HIM1, HIM2) of a previously very well characterized Fe-bearing elbaite from the Himalaya Mine (Ertl et al., 2010c) assuming that a Beer's Law calibration applies equally to all the crystals. The result infers that in the investigated tourmaline $21 \pm 2 \%$ of the total iron is in the $2+$ oxidation state.

\subsection{Crystal chemistry and structure analysis}

Analyses by a combination of electron microprobe (based on an average of 10 analyses), spectroscopic data and crystalstructure refinement result in the structural formula ${ }^{X}\left(\mathrm{Na}_{0.85} \mathrm{Ca}_{0.08} \mathrm{Sr}_{0.06} \mathrm{~K}_{0.01}\right)_{\Sigma 1.00}{ }^{Y}\left(\mathrm{Mg}_{1.68} \mathrm{Al}_{0.70} \mathrm{Fe}_{0.37}^{3+} \mathrm{Ti}_{0.10}^{4+} \mathrm{Fe}_{0.11}^{2+}\right.$
Table 4. Compositions (wt $\%$ and $a p f u$ ) of high-pressure tourmaline from the Kreuzeck Mountains, Eastern Alps, Austria.

\begin{tabular}{|c|c|c|c|c|}
\hline Constit. & Zone 1 & Zone 2 & Zone 3 & Zone 4 \\
\hline $\mathrm{SiO}_{2}$ & $35.52(31)$ & $34.42(20)$ & $35.30(6)$ & $34.54(12)$ \\
\hline $\mathrm{TiO}_{2}$ & $0.82(6)$ & $1.40(8)$ & $0.99(8)$ & $0.87(2)$ \\
\hline $\mathrm{Al}_{2} \mathrm{O}_{3}$ & $30.71(23)$ & $30.34(6)$ & $30.85(18)$ & $30.04(1)$ \\
\hline $\mathrm{Cr}_{2} \mathrm{O}_{3}$ & $0.08(3)$ & $0.11(3)$ & $0.10(3)$ & $0.59(2)$ \\
\hline $\mathrm{V}_{2} \mathrm{O}_{3}$ & $0.04(1)$ & $0.07(1)$ & $0.05(1)$ & $0.10(1)$ \\
\hline $\mathrm{FeO}_{\text {tot. }}$ & $3.87(6)$ & $5.19(15)$ & $5.28(4)$ & $3.63(5)$ \\
\hline $\mathrm{FeO}^{*}$ & 0.81 & 1.09 & 1.11 & 0.76 \\
\hline $\mathrm{Fe}_{2} \mathrm{O}_{3}{ }^{*}$ & 3.40 & 4.56 & 4.64 & 3.19 \\
\hline $\mathrm{MgO}$ & $10.14(18)$ & $9.08(13)$ & $8.88(7)$ & $9.92(3)$ \\
\hline $\mathrm{CaO}$ & $0.63(3)$ & $1.48(5)$ & $0.70(1)$ & $0.61(1)$ \\
\hline $\mathrm{SrO}$ & $0.59(5)$ & $0.20(1)$ & $0.37(2)$ & $0.64(2)$ \\
\hline $\mathrm{ZnO}$ & $0.04(1)$ & $0.03(1)$ & $0.04(3)$ & $0.02(0)$ \\
\hline $\mathrm{NiO}$ & $0.04(1)$ & $0.03(1)$ & $0.01(0)$ & $0.21(5)$ \\
\hline $\mathrm{PbO}_{2}$ & $0.02(1)$ & $0.03(1)$ & $0.06(4)$ & $0.54(4)$ \\
\hline $\mathrm{Na}_{2} \mathrm{O}$ & $2.69(6)$ & $2.21(11)$ & $2.68(2)$ & $2.66(2)$ \\
\hline $\mathrm{K}_{2} \mathrm{O}$ & $0.06(1)$ & $0.02(1)$ & $0.04(1)$ & $0.06(1)$ \\
\hline $\mathrm{B}_{2} \mathrm{O}_{3}{ }^{* *}$ & 10.95 & n.c. & n.c. & n.c. \\
\hline $\mathrm{H}_{2} \mathrm{O}^{* * * *}$ & 3.07 & n.c. & n.c. & n.c. \\
\hline $\mathrm{F}^{* *}$ & 0.38 & n.c. & n.c. & n.c. \\
\hline $\mathrm{O} \equiv \mathrm{F}$ & -0.16 & n.c. & n.c. & n.c. \\
\hline Sum & 99.83 & 85.04 & 85.82 & 84.75 \\
\hline $\mathrm{Si}$ & 5.82 & 5.74 & 5.82 & 5.75 \\
\hline${ }^{[4]} B^{* *}$ & 0.10 & 0.10 & 0.10 & 0.10 \\
\hline${ }^{[4]} \mathrm{Al}$ & 0.08 & 0.16 & 0.08 & 0.15 \\
\hline$\sum T$ site & 6.00 & 6.00 & 6.00 & 6.00 \\
\hline${ }^{[3]} \mathrm{B}$ & 3.00 & 3.00 & 3.00 & 3.00 \\
\hline $\mathrm{Ti}^{4+}$ & 0.10 & 0.18 & 0.12 & 0.11 \\
\hline $\mathrm{Al}$ & 5.85 & 5.80 & 5.91 & 5.74 \\
\hline $\mathrm{Cr}^{3+}$ & 0.01 & 0.02 & 0.01 & 0.08 \\
\hline $\mathrm{V}^{3+}$ & $<0.01$ & 0.01 & 0.01 & 0.01 \\
\hline $\mathrm{Fe}^{2+}$ & 0.11 & 0.15 & 0.15 & 0.11 \\
\hline $\mathrm{Fe}^{3+}$ & 0.42 & 0.58 & 0.58 & 0.40 \\
\hline $\mathrm{Mg}$ & 2.48 & 2.26 & 2.18 & 2.46 \\
\hline $\mathrm{Ca}$ & 0.03 & - & 0.03 & 0.04 \\
\hline $\mathrm{Zn}$ & $<0.01$ & $<0.01$ & 0.01 & $<0.01$ \\
\hline $\mathrm{Ni}$ & $<0.01$ & $<0.01$ & $<0.01$ & 0.03 \\
\hline $\mathrm{Pb}^{4+}$ & $<0.01$ & $<0.01$ & $<0.01$ & 0.02 \\
\hline$\Sigma Y+Z$ site & 9.00 & 9.00 & 9.00 & 9.00 \\
\hline $\mathrm{Ca}$ & 0.08 & 0.27 & 0.09 & 0.07 \\
\hline $\mathrm{Sr}$ & 0.06 & 0.02 & 0.04 & 0.06 \\
\hline $\mathrm{Na}$ & 0.85 & 0.71 & 0.86 & 0.86 \\
\hline $\mathrm{K}$ & 0.01 & $<0.01$ & 0.01 & 0.01 \\
\hline$\Sigma X$ site & 1.00 & 1.00 & 1.00 & 1.00 \\
\hline $\mathrm{OH}$ & 3.35 & n.c. & n.c. & n.c. \\
\hline $\mathrm{F}$ & 0.20 & n.c. & n.c. & n.c. \\
\hline
\end{tabular}

Note: n.c., not calculated. Zone 1, 10 analyses in the core region (crystal structure see Tables 1-3); Zone 2, 5 analyses (core region); Zone 3, 5 analyses (rim region); Zone 4, 2 analyses (rim region). Li (16-30 ppm) was determined on a bulk sample by ICP-MS (Konzett et al., 2012). Manganese and $\mathrm{Cl}$ are below detection limit.

*The proportions of $\mathrm{Fe}^{2+}$ and $\mathrm{Fe}^{3+}$ are calculated on the basis of optical spectroscopic investigation.

** $\mathrm{B}_{2} \mathrm{O}_{3}$ and $\mathrm{F}$ calculated according to SREF data (details in text); ${ }^{[4]} \mathrm{B}$ fixed at 0.10 apfu in zone $2-4$, based on SREF data of zone 1 . $* * * \mathrm{H}_{2} \mathrm{O}$ was calculated for a charge-balanced formula and to minimize the errors of the cation occupancies compared to the structure refinement (details see text). The formula of zone 1 was also calculated for $31(\mathrm{O}, \mathrm{OH}, \mathrm{F})$. As no evidence was found for vacancies at any site in zone 1 , the other zones were calculated for $X+Y+Z+T=15.9$ apfu, because we assumed 0.10 apfu ${ }^{[4]} \mathrm{B}$ to occur in each zone. 


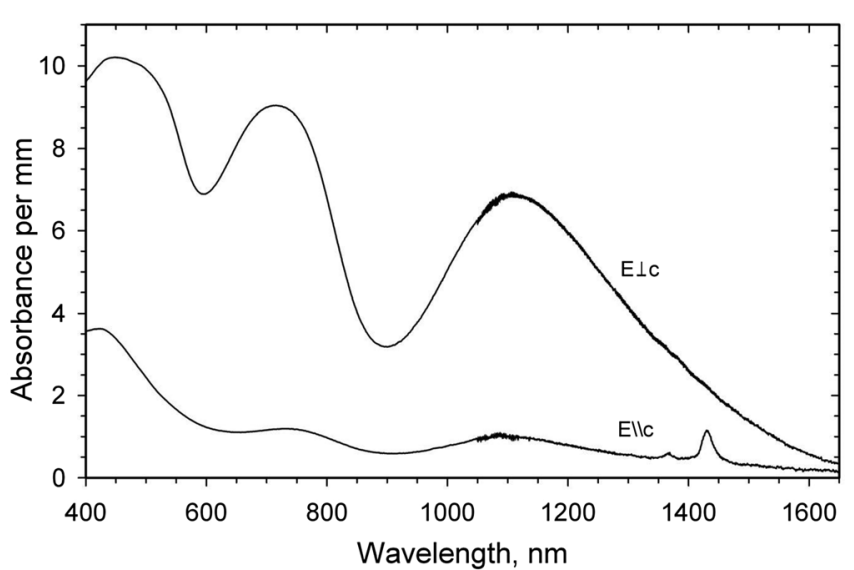

Fig. 2. Optical absorption spectra of tourmaline (sample GRR 3534) from the Kreuzeck Mountains, Eastern Alps, Austria.

$\left.\mathrm{Ca}_{0.03} \mathrm{Cr}_{0.01}^{3+}\right)_{\Sigma 3.00}{ }^{\mathrm{Z}}\left(\mathrm{Al}_{5.15} \mathrm{Mg}_{0.80} \mathrm{Fe}_{0.05}^{3+}\right)_{\Sigma 6.00}{ }^{T}\left(\mathrm{Si}_{5.82} \mathrm{~B}_{0.10} \mathrm{Al}_{0.08}\right.$ $\left.\mathrm{O}_{18}\right)\left(\mathrm{BO}_{3}\right)_{3}{ }^{V}(\mathrm{OH})_{3}{ }^{W_{[}}\left[\mathrm{O}_{0.45}(\mathrm{OH})_{0.35} \mathrm{~F}_{0.20}\right]$ for zone 1. All the assigned site-populations are in good agreement with the refined site-scattering values (Table 5).

The other zones were only characterized by electron microprobe. Because the $\mathrm{SiO}_{2}$ content was even lower than in zone 1 , we assumed 0.10 apfu ${ }^{[4]} \mathrm{B}$ to occur in each sample. The difference was calculated as ${ }^{[4]} \mathrm{Al}$. Because the $\mathrm{Fe}_{2} \mathrm{O}_{3}$ content in all zones is in the range of $~ 3.2-4.6 \mathrm{wt} \%$, the Z-site occupancy of zone 1 may also be close to that in the other zones. Hence the structural formulae for the other zones (2-4) can be given as:

\footnotetext{
Zone 2:

${ }^{X}\left(\mathrm{Na}_{0.71} \mathrm{Ca}_{0.27} \mathrm{Sr}_{0.02}\right)_{\Sigma 1.00}{ }^{Y}\left(\mathrm{Mg}_{1.46} \mathrm{Al}_{0.65} \mathrm{Fe}_{0.53}^{3+} \mathrm{Ti}^{4+}{ }_{0.18}\right.$ $\mathrm{Fe}_{0.15}^{2+} \mathrm{Cr}_{0.02}^{3+} \mathrm{V}_{0.01}^{3+}{ }^{3}{ }_{3.00}{ }^{Z}\left(\mathrm{Al}_{5.15} \mathrm{Mg}_{0.80} \mathrm{Fe}_{0.05}^{3+}\right)_{\Sigma 6.00}$ ${ }^{T}\left(\mathrm{Si}_{5.74} \mathrm{Al}_{0.16} \mathrm{~B}_{0.10} \mathrm{O}_{18}\right)\left(\mathrm{BO}_{3}\right)_{3}{ }^{V}(\mathrm{OH})_{3}{ }^{W_{[}}[\mathrm{O},(\mathrm{OH}), \mathrm{F}]$
}

Zone 3:

${ }^{X}\left(\mathrm{Na}_{0.86} \mathrm{Ca}_{0.09} \mathrm{Sr}_{0.04} \mathrm{~K}_{0.01}\right)_{\Sigma 1.00}{ }^{Y}\left(\mathrm{Mg}_{1.38} \mathrm{Al}_{0.76} \mathrm{Fe}_{0.53}^{3+} \mathrm{Ti}_{0.12}^{4+}\right.$ $\left.\mathrm{Fe}_{0.15}^{2+} \mathrm{Ca}_{0.03} \mathrm{Cr}_{0.01}^{3+} \mathrm{V}_{0.01}^{3+} \mathrm{Zn}_{0.01}\right)_{\Sigma 3.00}$

${ }^{Z}\left(\mathrm{Al}_{5.15} \mathrm{Mg}_{0.80} \mathrm{Fe}_{0.05}^{3+}\right)_{\Sigma 6.00}{ }^{T}\left(\mathrm{Si}_{5.82} \mathrm{~B}_{0.10} \mathrm{Al}_{0.08} \mathrm{O}_{18}\right)$ $V_{(\mathrm{OH})}{ }^{\left.W_{[} \mathrm{O},(\mathrm{OH}), \mathrm{F}\right]}$

Zone 4:

${ }^{X}\left(\mathrm{Na}_{0.85} \mathrm{Ca}_{0.08} \mathrm{Sr}_{0.06} \mathrm{~K}_{0.01}\right)_{\Sigma 1.00}{ }^{Y}\left(\mathrm{Mg}_{1.66} \mathrm{Al}_{0.59} \mathrm{Fe}_{0.35}^{3+} \mathrm{Ti}_{0.11}^{4+}\right.$ $\left.\mathrm{Fe}_{0.11}^{2+} \mathrm{Cr}_{0.08}^{3+} \mathrm{Ca}_{0.04} \mathrm{Ni}_{0.03} \mathrm{~Pb}_{0.02}^{4+} \mathrm{V}_{0.01}^{3+}\right)_{\Sigma 3.00}{ }^{Z}\left(\mathrm{Al}_{5.15} \mathrm{Mg}_{0.80}\right.$ $\left.\mathrm{Fe}_{0.05}^{3+}\right)_{\Sigma 6.00}{ }^{T}\left(\mathrm{Si}_{5.75} \mathrm{Al}_{0.15} \mathrm{~B}_{0.10} \mathrm{O}_{18}\right)\left(\mathrm{BO}_{3}\right)_{3}{ }^{V}(\mathrm{OH})_{3}{ }^{W}[\mathrm{O},(\mathrm{OH}), \mathrm{F}]$.

\section{3. $X$-site occupancy}

The $X$ site in all zones is mainly occupied by $\mathrm{Na}(\sim 0.7-0.9$ apfu). Additionally minor amounts of $\mathrm{Ca}(0.08-0.27$ apfu) and $\mathrm{Sr}(0.02-0.06$ apfu $)$ and traces of $\mathrm{K}(\leq 0.01$ apfu $)$ occupy this site. When the $(\mathrm{OH})$ content was calculated for $(Y+Z+T)=15$ atoms per formula unit (apfu), the sum of $(\mathrm{Na}+\mathrm{Ca}+\mathrm{Sr}+\mathrm{K})$ was exactly 1.00 apfu for one sample (zone 2), but $>1.00$ apfu for the other three zones.
Table 5. Refined site-scattering values (SREF; epfu), assigned sitepopulations (apfu) and equivalent site-scattering values (EMPA; epfu) for tourmaline from the Kreuzeck Mountains, Eastern Alps, Austria.

\begin{tabular}{lcll}
\hline & SREF & \multicolumn{1}{c}{ Site population } & EMPA \\
\hline$X$ & $12.9(5)^{*}$ & $0.85 \mathrm{Na}+0.08 \mathrm{Ca}+0.06$ & 13.4 \\
& & $\mathrm{Sr}+0.01 \mathrm{~K}$ & \\
$Y$ & $44.2(4)$ & $1.68 \mathrm{Mg}+0.70 \mathrm{Al}+0.48$ & 44.8 \\
& & $\mathrm{Fe}+0.10 \mathrm{Ti}+0.03 \mathrm{Ca}+0.01 \mathrm{Cr}$ & \\
$Z$ & $77.9(4)^{* *}$ & $5.15 \mathrm{Al}+0.80 \mathrm{Mg}+0.05 \mathrm{Fe}$ & 77.9 \\
\hline
\end{tabular}

Note: *Refining $\mathrm{Na} \leftrightarrow \mathrm{Ca}$ at the $X$ site by using the same $\mathrm{X}$-ray data gave the value 13.4(1) epfu.

**This value was estimated by releasing the Z-site occupancy in a preliminary refinement.

It was still too high if the $\mathrm{OH}$ content was increased further and $Y$-site vacancies were all allowed. Therefore we checked the possibility that each cation, which usually occupies the [9]-coordinated $X$ site, could also occupy another atomic position. It is unlikely that $\mathrm{Sr}^{2+}$ and $\mathrm{K}^{1+}$ occupy a site other than the $X$ site, because of their relatively large effective ionic radii. Compared to $\mathrm{Na}^{1+}(1.24 \AA), \mathrm{Ca}^{2+}(1.18 \AA)$ has a significantly smaller ionic radius (Shannon, 1976). Hence, the likelihood for Ca to occupy a [6]-coordinated position is the highest among all these cations. At the [6]-coordinated $Y$ site Ca would have an effective ionic radius of $1.00 \AA$, which would be $20 \%$ higher than the ionic radius of $\mathrm{Mn}^{2+}$ $(0.83 \AA)$. The tourmaline structure is known to be very flexible and therefore we assigned small amounts of $\mathrm{Ca}(\leq 0.04$ $a p f u$ ) to the $Y$ site of this high-pressure tourmaline, so as not to exceed the $1.00 a p f u$ at the $X$ site. Another explanation for this observation might be analytical errors.

Zone 4 contains additionally $0.02 \mathrm{~Pb}$ apfu. Because in this tourmaline $\sim 80 \%$ of the total $\mathrm{Fe}$ is oxidized, it is likely that also $\mathrm{Pb}$ is oxidized to $\mathrm{Pb}^{4+}$. In a [6]-coordination $\mathrm{Pb}^{4+}$ has an effective ionic radius of $0.78 \AA$ (Shannon, 1976), which is very similar to $\mathrm{Fe}^{2+}(0.78 \AA)$ and $\mathrm{Mg}(0.72 \AA)$. Therefore we assigned these small amounts of $\mathrm{Pb}$ to the $Y$ site and not to the $X$ site.

It is important to note that significant amounts of $\mathrm{Sr}$ were verified to occupy the $X$ site in the tourmaline structure for the first time. Refining $\mathrm{Na} \leftrightarrow \mathrm{Sr}$ gave a very similar result to what was found with microprobe analysis (Table 5). This is the highest amount of $\mathrm{Sr}$ (up to $0.68 \mathrm{wt} \% \mathrm{SrO}$ ) in any tourmaline structure. By refining $\mathrm{Na} \leftrightarrow \mathrm{Ca}$ at the $X$ site (all other sites were refined as before) in a preliminary refinement, the refined site-scattering value increases slightly, but gives also a very similar result. Such slight differences are within errors of the refinements.

\section{4. $Y$ - and $Z$-site occupancy}

The $Y$ site is in all zones dominantly occupied by $\mathrm{Mg}$ (1.4-1.7 apfu). But not all $\mathrm{Mg}$ is ordered into the $Y$ site (based on the structure refinement). Because of a significant disorder some $\mathrm{Mg}$ (0.8 apfu) occupies also the $Z$ site. Aluminium is the second most abundant cation at the $Y$ site 
( 0.6-0.8 apfu). Further cations with significant amounts at the $Y$ site are $\mathrm{Fe}^{3+}\left(0.4-0.5\right.$ apfu), $\mathrm{Ti}^{4+}$ and $\mathrm{Fe}^{2+}$ (both 0.10.2 apfu). Very small amounts of $\mathrm{Cr}^{3+}, \mathrm{V}^{3+} ; \mathrm{Ni}^{2+}, \mathrm{Zn}^{2+}$, $\mathrm{Ca}^{2+}$ and $\mathrm{Pb}^{4+}$ may also occur at this site. The assigned $Z$-site occupancy with $\left(\mathrm{Al}_{5.15} \mathrm{Mg}_{0.80} \mathrm{Fe}_{0.05}^{3+}\right)$ is in good agreement with the refined site-scattering values (Table 5) and with the enlarged $\langle Z-\mathrm{O}\rangle$ distance of $1.927 \AA$ (Table 3 ) as compared to $<\mathrm{Al}-\mathrm{O}>$.

\section{5. $T$-site occupancy}

The $<T-\mathrm{O}>$ distance of $\sim 1.6185 \AA$ (Table 3 ) is also in good agreement with a $T$ site occupied by $\left(\mathrm{Si}_{5.82} \mathrm{~B}_{0.10} \mathrm{Al}_{0.08}\right)$. To fill the $T$ site after considering the refined ${ }^{[4]} \mathrm{B}$ value of 0.10(2) apfu (Table 2), small amounts of ${ }^{[4]} \mathrm{Al}$ seem also to occupy this site. Tourmalines with such $T$-site occupancies including $\mathrm{Si}$ and small amounts of ${ }^{[4]} \mathrm{B}$ and ${ }^{[4]} \mathrm{Al}$ have already been described (Ertl et al., 2005, 2010c; Lussier et al., 2009). A $T$-site occupancy assigned with $\left(\mathrm{Si}_{5.82} \mathrm{Al}_{0.18}\right)$ would produce a $\langle T-\mathrm{O}\rangle$ distance between 1.621 and $1.622 \AA$ (Ertl et al., 2016). This would be significantly higher than the observed $\langle T-\mathrm{O}\rangle$ distance. Hence, a mixed occupation with $\mathrm{Si}$ and small amounts of ${ }^{[4]} \mathrm{B}$ and ${ }^{[4]} \mathrm{Al}$ seems to be likely.

\section{6. $V$ - and $W$-site occupancy}

An $\mathrm{H}$ atom (H3) at the site associated with $\mathrm{O} 3$ was easily located in the refinement. Ertl et al. (2002) showed that the bond-angle distortion $\left(\sigma_{\text {oct }}{ }^{2}\right)$ of the $\mathrm{ZO}_{6}$ octahedron in a tourmaline is largely a function of the $\langle Y-\mathrm{O}\rangle$ distance in that tourmaline, although the occupant of the $\mathrm{O}(3)$ site $(V$ site in the general formula) also affects that distortion. The correlation coefficient, $r$, of $\langle Y-\mathrm{O}\rangle$ and $\sigma_{\text {oct }}{ }^{2}$ of the $Z_{6}$ octahedron is -0.99 (Fig. 2 in Ertl et al., 2005) for all investigated tourmalines whose $V$ site is occupied by three $(\mathrm{OH})$ groups. The high-pressure tourmaline (with ${ }^{Z} \sigma_{\text {oct }}{ }^{2}=45.89$ and $<Y-\mathrm{O}>2.029 \AA$; Table 3) lies exactly on the $V$ site $=3$ $(\mathrm{OH})$ line. Hence, the $V$ site of this high-pressure tourmaline is completely occupied by $(\mathrm{OH})_{3}$. Essentially, no $\mathrm{H}$ associated with the $\mathrm{O}(1)$ site ( $W$ site) was found by refinement. However, small amounts of $\mathrm{H}$ can not be detected by refinement accurately. Hence, this site is dominated by oxygen, as indicated by the chemical composition. There is also a minor $(\mathrm{OH})$ and $\mathrm{F}$ occupancy at this $W$ site. The amount of $\mathrm{OH}$ $(\sim 0.35 \mathrm{apfu})$ was iteratively calculated for a charge-balanced formula and to minimize the errors of the cation occupancies compared to the structure refinement. Another interesting possibility for a calculation of the $\mathrm{OH}$ content is reported by Bosi $(2013):{ }^{W}(\mathrm{OH})=[2-1.01 \mathrm{BVS}(\mathrm{O} 1)-0.21-\mathrm{F}]$, where $\mathrm{BVS}(\mathrm{O} 1)$ is the bond-valence sum at $\mathrm{O} 1(W)$ and $\mathrm{F}$ is in apfu. For the studied tourmaline this calculation yields for a BVS $(\mathrm{O} 1)$ of 1.35 valence units and for a $\mathrm{F}$ content of $0.20(5)$ apfu (Table 2) a ${ }^{W}(\mathrm{OH})$ content of $0.23(5)$ apfu. Considering the errors both values are in good agreement with each other.

It is not surprising that the $W$ site contains a relatively high amount of oxygen, because $\sim 80 \%$ of the Fe content is oxidized to $\mathrm{Fe}^{3+}$. To produce a charge-balanced formula $\mathrm{H}$ atoms have to be released. Because of the relatively large error of the estimated amount of $(\mathrm{OH})$, the classification of the studied tourmaline sample is problematic, but it seems that it belongs to the dravite - oxy-dravite - buergerite series.

\section{Discussion and conclusion}

How can the relatively high $\mathrm{Sr}$ content, with up to $0.68 \mathrm{wt} \%$ $\mathrm{SrO}$ and the significant $\mathrm{Pb}$ content, with up to $0.54 \mathrm{wt} \%$ $\mathrm{PbO}_{2}$, in the tourmaline structure be explained? Primary aqueous saline fluid inclusions trapped in quartz coexisting with tourmaline under eclogite-facies $P-T$ conditions show relatively high concentrations of $\mathrm{Sr}, \mathrm{B}$ and also of some $\mathrm{Pb}$ (Konzett et al., 2012). The $\mathrm{Sr}$ content is the highest observed in tourmaline to date. A possible source of B is the metapelitic country rocks with tourmaline-bearing pegmatites, which intruded during Permian times. A crustal source of $\mathrm{B}$ would be consistent with relatively high $\mathrm{Li}$ concentrations of 5-8 $\mu \mathrm{g} \mathrm{g}^{-1} \mathrm{Li}$ in zircon, intergrown with the tourmaline (Konzett et al., 2012). The tourmaline itself is enriched in $\mathrm{Mg}$ and $\mathrm{Fe}$ (Table 4).

Commonly, tourmaline-bearing pegmatites of the Austroalpine basement units and many other occurrences are in contact with marbles (Beck, 1936; Höller, 1959; Esterlus, 1983; Bernhard, 2009; Ertl et al., 2010a; Pfaffl, 2012). A pegmatite from the Austroalpine basement, in contact to mylonitic garnet micaschist and to marble, which was found at the Koralpe, Eastern Alps, Styria, Austria, contains Al-rich tourmaline with 189 ppm Sr (Ertl et al., 2006).

Magnesium-rich tourmalines from the contact zone of Permian pegmatites to mica schists and marbles from different localities of the Austroalpine basement units (Rappold Complex) in Styria, Austria, contain up to $142 \mathrm{ppm} \mathrm{Sr}$ (Ertl et al., 2010a). These authors concluded that the pegmatites were formed by anatectic melting of mica schists and paragneisses in Permian time and that they crystallized from the pegmatitic melt, and were influenced by the metacarbonate and metapelitic host rocks (Ertl et al., 2010a). Another tourmaline (fluor-liddicoatite) was found at the border zone of a pegmatite of the Austroalpine basement units, near Altes Almhaus, Stubalpe, Styria. The tourmaline- and spodumene-bearing pegmatite crosscuts a marble from where $\mathrm{Ca}$ was mobilized, which is also responsible for the crystallization of this Ca-dominant tourmaline (Ertl et al., 2013).

More than 60 samples of calcitic and a few dolomitic marbles of the greenschist- to eclogite-facies Austroalpine basement (Eastern Alps) were investigated by Puhr et al. (2008). These authors further described some marbles containing up to 1300 ppm Sr. Carbonate is generally known to be the most important carrier rock of $\mathrm{Sr}$.

In plagioclase-muscovite-scapolite metaevaporite layers in dolomite marble near Prosetín (Moravicum, Czech Republic), blue-grey $\mathrm{Mg}$-rich tourmalines were found to contain up to 337 ppm Sr (Bačík et al., 2012). These authors found a positive correlation between $\mathrm{Sr}$ and $\mathrm{Ca}$ in tourmaline $\left(r^{2}=0.77\right)$. Some tourmaline analyses correspond to 
oxy-dravite and some others to magnesio-foitite. The unit-cell parameters $[a=15.912, c=7.199 \AA]$ and the calculated average bond lengths $(\langle Y-\mathrm{O}\rangle=1.995 \AA$; $\langle Z-\mathrm{O}\rangle=$ $1.929 \AA$ A $)$ indicate also a relatively high $\mathrm{Al}-\mathrm{Mg}$ disorder (Bačík et al., 2012).

The Anjanabonoina pegmatites in Madagascar are famous for their large and multicoloured Ca-rich tourmalines (liddicoatite). These pegmatite dikes are emplaced in a complex environment characterized by gneisses and marbles of medium metamorphic grade (De Vito et al., 2006). The metasedimentary rocks hosting the pegmatitic dikes locally show extensive contact-metasomatic phenomena. Veins of quartz and tourmaline occur in metasedimentary rocks close to the pegmatites, and marble is transformed into skarn (De Vito et al., 2006). An Al-rich tourmaline from such a pegmatite contains $273 \mathrm{ppm} \mathrm{Sr}$ (Ertl et al., 2006).

As mentioned, $\mathrm{Mg}$-rich tourmaline from Outokumpu, Finland, contains $0.34 \mathrm{wt} \% \mathrm{SrO}$ (Peltola et al., 1968). This tourmaline contains $10.6 \mathrm{wt} \% \mathrm{MgO}, 9.6 \mathrm{wt} \% \mathrm{Cr}_{2} \mathrm{O}_{3}$ and $0.6 \mathrm{wt} \% \mathrm{~V}_{2} \mathrm{O}_{3}$. It occurs in contact skarns between serpentinites and quartzites. The authors described indications that this tourmaline is a product of an interaction of serpentinites with metasomatic dolomitic marble and quartzite (Peltola et al., 1968). The unit-cell parameters of this Sr-bearing, $\mathrm{Mg}$-rich tourmaline from Outokumpu are very similar to the unit-cell parameters of the tourmaline investigated here (Table 1), which contains a similar amount of $\mathrm{Mg}$ (8.9$10.1 \mathrm{wt} \% \mathrm{MgO})$, much lower amounts of $\mathrm{Cr}^{3+}(0.1-0.6$ wt $\left.\% \mathrm{Cr}_{2} \mathrm{O}_{3}\right)$ and $\mathrm{V}^{3+}\left(\leq 0.1 \mathrm{wt} \% \mathrm{~V}_{2} \mathrm{O}_{3}\right.$; Table 4$)$, and an amount of $\mathrm{Sr}^{2+}$ that can be twice as high as from Outokumpu. The investigated tourmaline zones exhibit a significant $\mathrm{CaO}$ content (0.6-1.5 wt\% $\mathrm{CaO}$; Table 4).

The possibility should also be considered that the original boron sources for tourmaline crystallization in the eclogite from the Kreuzeck Mountains, namely Permian tourmaline-bearing pegmatites, were influenced by a Sr-enriched metacarbonate, maybe by a dolomitic marble. In the eclogite, $\mathrm{Sr}$ and $\mathrm{Ca}$ concentrations of fluid inclusions in quartz (coexisting with tourmaline) show a nearly linear positive correlation (Konzett et al., 2012). In such fluid inclusions, calcite daughter crystals were also identified by these authors.

In a "mushroom" tourmaline from Myanmar, which is enriched in $\mathrm{Al}$ and $\mathrm{B}$, a significant amount of $\mathrm{Pb}(0.18 \mathrm{wt} \%$ $\mathrm{PbO}$ ) was reported (Ertl et al., 2007). In that work also tourmaline samples with a significant amount of $\mathrm{Pb}$ from other localities were discussed. In absence of any other data, we assumed that in our investigated tourmaline $\mathrm{Pb}$ is in a 4+ oxidation state, because $\sim 80 \%$ of the $\mathrm{Fe}$ is oxidized to $\mathrm{Fe}^{3+}$. Hence, we assign the small $\mathrm{Pb}$ amount of 0.02 apfu to the $Y$ site rather than the $X$ site (Table 4).

Because only a small amount of F (0.20 apfu; Table 2) was estimated by refinement, and the amount of $(\mathrm{OH})$ was only estimated to $0.35 \mathrm{apfu}$, the $W$ site seems to be dominated by oxygen. Therefore the composition of this high-pressure tourmaline has a significant oxy-dravite component, which would be in agreement with a significant amount of oxidized $\mathrm{Fe}$ in our sample. Oxy-dravite was approved as a new species by the IMA in 2012 and described by Bosi \& Skogby (2013). A further investigation of the exact location of the two proton sites was done by Gatta et al. (2014).

Based on this data review, we recommend for tourmalines with $\mathrm{MgO}>8 \mathrm{wt} \%$ and which contain significant $\mathrm{Ca}$ amounts (notably when the tourmaline-bearing rock is in contact with a carbonate) that analyses be obtained also for $\mathrm{Sr}$ and $\mathrm{Pb}$. Especially tourmalines from metamorphic rocks or from contact skarns could be of particular interest. Sometimes such Sr-bearing tourmalines can also contain significant amounts of $\mathrm{Cr}, \mathrm{V}$ and $\mathrm{Ni}$.

Acknowledgements: This work was supported in part by Austrian Science Fund (FWF) project no. P31049-N29 to $\mathrm{AE}$ and NSF grant EAR-1322082 to GRR. We thank Darrell J. Henry and two anonymous reviewers for their constructive reviews.

\section{References}

Bačík, P., Uher, P., Cempírek, J., Vaculovič, T. (2012): Magnesian tourmalines from plagioclase-muscovite-scapolite metaevaporite layers in dolomite marble near Prosetín (Olešnice Unit, Moravicum, Czech Republic). J. Geosci., 57, 143-153.

Beck, H. (1936): Aufnahmsbericht des Chefgeologen Dr. Heinrich Beck über Blatt Mölltal (5250). Verh. Geol. B.-A., 1936, 43-45.

Bernhard, F. (2009): Wildbachgraben (Steinbruch Gupper II/ Aldrian), Deutschlandsberg, Koralpe, Steiermark. http://www. geocities.ws/franz11at/GupperII_Wildbachgraben.pdf (accessed 27.2.2019).

Bosi, F. (2013): Bond-valence constraints around the O1 site of tourmaline. Mineral. Mag., 77, 343-351.

- (2018): Tourmaline crystal chemistry. Am. Mineral., 103, 298-306.

Bosi, F. \& Lucchesi, S. (2004): Crystal chemistry of the schorldravite series. Eur. J. Mineral., 16, 335-344.

- , - (2007): Crystal chemical relationships in the tourmaline group: structural constraints on chemical variability. Am. Mineral., 92, 1050-1063.

Bosi, F. \& Skogby, H. (2013): Oxy-dravite, $\mathrm{Na}\left(\mathrm{Al}_{2} \mathrm{Mg}\right)\left(\mathrm{Al}_{5} \mathrm{Mg}\right)$ $\left(\mathrm{Si}_{6} \mathrm{O}_{18}\right)\left(\mathrm{BO}_{3}\right)_{3}(\mathrm{OH})_{3} \mathrm{O}$, a new mineral species of the tourmaline supergroup. Am. Mineral., 98, 1442-1448.

Bruker AXS Inc. (2001): SaintPlus, Version 6.45. Bruker AXS Inc., Madison, WI, USA.

Buerger, M.J., Burnham, C.W., Peacor, D.R. (1962): Assessment of the several structures proposed for tourmaline. Acta Crystal$\log r ., 15,583-590$.

De Vito, C., Pezzotta, F., Ferrini, V., Aurisicchio, C. (2006): Nb-TiTa oxides in the gem-mineralized and "hybrid" Anjanabonoina granitic pegmatite, central Madagascar: a record of magmatic and postmagmatic events. Can. Mineral., 44, 87-103.

Ertl, A. \& Hughes, J.M. (2002): Crystal structure of aluminum-rich schorl overgrown by boron-rich olenite from Stoffhütte, Koralpe, Austria. Mineral. Petrol., 75, 69-78.

Ertl, A., Pertlik, F.,Bernhardt, H.-J. (1997): Investigations on olenite with excess boron from the Koralpe, Styria, Austria. Österr. Akad. Wiss., Math.-Naturw. Kl., Abt. I, Anzeiger, 134, 3-10.

Ertl, A., Hughes, J.M., Pertlik, F., Foit, F.F. Jr., Wright, S.E., Brandstätter, F., Marler, B. (2002): Polyhedron distortions in tourmaline. Can. Mineral., 40, 153-162.

Ertl, A., Rossman, G.R., Hughes, J.M., Prowatke, S., Ludwig, T. (2005): Mn-bearing "oxy-rossmanite" with tetrahedrally-coordinated Al and B from Austria: structure, chemistry, and infrared and optical spectroscopic study. Am. Mineral., 90, 481-487. 
Ertl, A., Hughes, J.M., Prowatke, S., Ludwig, T., Prasad, P.S.R., Brandstätter, F., Körner, W., Schuster, R., Pertlik, F., Marschall, H. (2006): Tetrahedrally-coordinated boron in tourmalines from the liddicoatite-elbaite series from Madagascar: structure, chemistry, and infrared spectroscopic studies. Am. Mineral., 91, 1847-1856.

Ertl, A., Hughes, J.M., Prowatke, S., Ludwig, T., Brandstätter, F., Körner, W., Dyar, M.D. (2007): Tetrahedrally-coordinated boron in Li-bearing olenite from "mushroom" tourmaline from Momeik, Myanmar. Can. Mineral., 45, 891-899.

Ertl, A., Tillmanns, E., Ntaflos, T., Francis, C., Giester, G., Körner, W., Hughes, J.M., Lengauer, C., Prem, M. (2008): Tetrahedrally coordinated boron in Al-rich tourmaline and its relationship to the pressure-temperature conditions of formation. Eur. J. Mineral., 20, 881-888.

Ertl, A., Mali, H., Schuster, R., Körner, W., Hughes, J.M., Brandstätter, F., Tillmanns, E. (2010a): Li-bearing, disordered $\mathrm{Mg}$-rich tourmalines from the pegmatite-marble contact from the Austroalpine basement units (Styria, Austria). Mineral. Petrol., 99, 89-104.

Ertl, A., Marschall, H.R., Giester, G., Henry, D.J., Schertl, H.-P., Ntaflos, T., Luvizotto, G.L., Nasdala, L., Tillmanns, E. (2010b): Metamorphic ultra high-pressure tourmalines: structure, chemistry, and correlations to PT conditions. Am. Mineral., 95, 1-10.

Ertl, A., Rossman, G.R., Hughes, J.M., London, D., Wang, Y., O'Leary, J.A., Dyar, M.D., Prowatke, S., Ludwig, T., Tillmanns, E. (2010c): Tourmaline of the elbaite-schorl series from the Himalaya Mine, Mesa Grande, California, U.S.A.: a detailed investigation. Am. Mineral., 95, 24-40.

Ertl, A., Tillmanns, E., Schuster, R., Hughes, J.M., Meyer, H.-P., Ludwig, T., Mail, H. (2013): Tetrahedrally-coordinated Al in Mn-rich liddicoatite from a pegmatite-marble contact in the Austroalpine basement units. in "Abstracts, Joint Annual Meeting DMG and GV, Tübingen, Germany, 16th to 19th September 2013", 80 p.

Ertl, A., Kolitsch, U., Dyar, M.D., Meyer, H.-P., Henry, D.J., Rossman, G.R., Prem, M., Ludwig, T., Nasdala, L., Lengauer, C.L., Tillmanns, E., Niedermayr, G. (2016): Fluor-schorl, a new member of the tourmaline supergroup, and new data on schorl from the cotype localities. Eur. J. Mineral., 28, 163-177.

Esterlus, M. (1983): Kurzer Überblick über die Pegmatite im Angerkristallin der Oststeiermark. Arch. Lagerstättenforschung Geol. B.-A., 3, 31-34.

Fischer, R.X. \& Tillmanns, E. (1988): The equivalent isotropic displacement factor. Acta Crystallogr., C44, 775-776.

Foit, F.F. Jr. (1989): Crystal chemistry of alkali-deficient schorl and tourmaline structural relationships. Am. Mineral., 74, 422-431.

Gatta, G.D., Bosi, F., McIntyre, G.J., Skogby, H. (2014): First accurate location of two proton sites in tourmaline: a singlecrystal neutron diffraction study of oxy-dravite. Mineral. Mag., 78, 681-692.

Hawthorne, F.C. (1996): Structural mechanisms for light-element variations in tourmaline. Can. Mineral., 34, 123-132.

- (2002): Bond-valence constraints on the chemical composition of tourmaline. Can. Mineral., 40, 789-797.
Henry, D.J., Novák, M., Hawthorne, F.C., Ertl, A., Dutrow, B.L., Uher, P., Pezzotta, F. (2011): Nomenclature of the tourmaline supergroup-minerals. Am. Mineral., 96, 895-913.

Höller, H. (1959): Ein Spodumen-Beryll-Pegmatit und ein mineralreicher Marmor im Wildbachgraben bei Deutschlandsberg. Mitt. Abt. Mineral. Joanneum, 1, 19.

Hughes, J.M., Ertl, A., Dyar, M.D., Grew, E., Wiedenbeck, M., Brandstätter, F. (2004): Structural and chemical response to varying ${ }^{[4]} \mathrm{B}$ content in zoned Fe-bearing olenite from Koralpe, Austria. Am. Mineral., 89, 447-454.

Konzett, J., Krenn, K., Hauzenberger, Ch, Whitehouse, M., Hoinkes, G. (2012): High-pressure tourmaline formation and fluid activity in Fe-Ti-rich eclogites from the Kreuzeck Mountains, Eastern Alps, Austria. J. Petrol., 53, 99-125.

Lussier, A.J., Aguiar, P.M., Michaelis, V.K., Kroeker, S., Herwig, S., Abdu, Y., Hawthorne, F.C. (2008): Mushroom elbaite from the Kat Chay mine, Momeik, near Mogok, Myanmar: I. Crystal chemistry by SREF, EMPA, MAS NMR and Mössbauer spectroscopy. Mineral. Mag., 72, 747-761.

Lussier, A.J., Aguiar, P.M., Michaelis, V.K., Kroeker, S., Hawthorne, F.C. (2009): The occurrence of tetrahedrally coordinated $\mathrm{Al}$ and $\mathrm{B}$ in tourmaline: an ${ }^{11} \mathrm{~B}$ and ${ }^{27} \mathrm{Al}$ MAS NMR study. Am. Mineral., 94, 785-792.

MacDonald, D.J. \& Hawthorne, F.C. (1995): The crystal chemistry of $\mathrm{Si} \leftrightarrow \mathrm{Al}$ substitution in tourmaline. Can. Mineral., 33, $849-858$.

Mattson, S.M. \& Rossman, G.R. (1987): $\mathrm{Fe}^{2+}-\mathrm{Fe}^{3+}$ interactions in tourmaline. Phys. Chem. Minerals, 14, 163-171.

Peltola, E., Vuorelainen, Y., Häkli, T.A. (1968): A chromian tourmaline from Outokumpu, Finland. Bull. Geol. Soc. Finland, 40, 35-38.

Pfaffl, F. (2012): Vierfarbige Turmaline von Schüttenhofen (Sušice) im Böhmerwald/Tschechien. Der Bayerische Wald, 25, 81 .

Puhr, B., Schuster, R., Hoinkes, G., Moshammer, B. (2008): Strontium, Carbon and Oxygen Isotope Study on Marbles of the Greenschist to Eclogite Facies Austroalpine Basement (Eastern Alps): tectonic and Stratigraphic Implications. in "Abstracts, DMG 86th Annual Meeting 14th to 17th September 2008, Berlin, Germany”, 307 p.

Shannon, R.D. (1976): Revised effective ionic radii and systematic studies of interatomic distances in halides and chalcogenides. Acta Crystallogr., A32, 751-767.

Sheldrick, G.M. (1997): SHELXL-97, a program for crystal structure refinement. University of Göttingen, Germany.

Sheldrick, G.M. (2008): A short history of SHELX. Acta Crystallogr., A64, 112-122.

Taran, M.N. \& Rossman, G.R. (2001): Optical spectra of $\mathrm{Co}^{2+}$ in three synthetic silicate minerals. Am. Mineral., 86, 889-895.

Received 4 March 2019

Modified version received 25 April 2019

Accepted 26 April 2019 